\title{
Telomere Length as a Biomarker of Biological Aging in Shift Workers
}

\author{
Caterina Ledda $1, *\left(\mathbb{0}\right.$, Carla Loreto $^{2}$ and Venerando Rapisarda ${ }^{1}$ \\ 1 Occupational Medicine, Department of Clinical and Experimental Medicine, University of Catania, \\ 95123 Catania, Italy; vrapisarda@unict.it \\ 2 Anatomy and Histology, Department of Biomedical and Biotechnological Sciences, University of Catania, \\ 95123 Catania, Italy; carla.loreto@unict.it \\ * Correspondence: cledda@unict.it
}

Received: 27 January 2020; Accepted: 13 April 2020; Published: 16 April 2020

check for updates

\begin{abstract}
Shift work (SW) comprises a work schedule that involves recurring times of nonstandard work hours balanced to a fixed daily work plan with regular day work times and has been evaluated as "probably carcinogenic to humans" (Group 2A) by IARC. SW may result in increased age acceleration. This systematic review aims to elucidate the usefulness of telomere length as a biomarker of biological aging in shift workers. All studies analyzed underline a shortening of telomere length in SW, and aging in shift workers and duration of work. Methodologies to measure biological aging are possible to advance efforts to clarify the basic biology of aging and provide clinicians an instrument to communicate complex health advice to workers. Telomere length measures can also give an instrument for precision medicine, useful for occupational physicians in age-related screening conditions.
\end{abstract}

Keywords: CLOCK gene; circadian rhythms; workers; night work; shift work; inflammation; cancer; aging

\section{Introduction}

Shift work (SW) comprises a work schedule that involves recurring times of nonstandard work hours balanced to a fixed daily work plan with regular day work times [1,2]. SW can include early morning, afternoon, evening, or night shifts and may be scheduled to fixed or rotational (i.e., rotating among mornings, afternoons, and nights) timetables [2].

In Europe, it has been estimated that $17 \%$ of workers [3] are implicated in SW, and the number is always increasing, due to new job demands [4].

In 2007, the International Agency for Research on Cancer (IARC) classified shift work (SW) as "probably carcinogenic to humans" (Group 2A) and more recently, in 2019, IARC classified Night Shift Work (NSW) as "probably carcinogenic to humans" (Group 2A) by [5] for breast, prostate, and colon, founded on limited evidence of cancer in humans, sufficient evidence of cancer in experimental animals, and strong mechanistic evidence in experimental animals [5].

SW, mainly the category linking working at night, is correlated with circadian rhythm disruption that determines trouble falling asleep, shortened sleep, and daytime fatigue [2,6,7]. Moreover, several investigations have highlighted that SW [8,9] and misalignment of sleep [10] may affect cognitive functions. SW may modify lifestyle features, which could be a factor in the pathway between SW and cognitive performances [1,11]. Recently, it was demonstrated that SW might have effects on biological aging [12].

Recently, many researchers have focused their attention on the genes of the circadian clock, a sequence of genes implicated on preserving the inside organization of numerous oscillators inside and among organs systems [13]. The Circadian Locomotor Output Cycles Kaput (CLOCK) gene is wildly investigated for this purpose: it codifies for the CLOCK protein, a favorable regulatory hand of 
the circadian system [13]. Variations of the CLOCK gene are usually given by SW and sleep deprivation or by the genetic distinction of the CLOCK gene [14]. This modification has been correlated with numerous physiological and pathological issues [14].

Notably, disparities of the CLOCK gene have been correlated with the initiation of obesity, type 2 diabetes, sleep and mood diseases, and cancer [15-17]. Concerning aging, a low number of investigations have studied the potential role of the CLOCK gene on longevity or aging $[18,19]$.

Aging is a physiological progression that causes significant alterations in biological variables and organ functions. Some investigations have underlined a function of the CLOCK gene on several features of the life span development, recommending a probable link among this gene and aging [20-22]. The protein encodes a transcription agent of the basic helix-loop-helix (bHLH) family and includes DNA required for the activity of histone acetyltransferase. The ARNTL (BMAL1), an encoded protein structure, attaches E-box enhancer elements upstream of Period (PER1, PER2, PER3) and Cryptochrome (CRY1, CRY2) genes, and starts transcription of those genes. PER and CRY proteins heterodimerize and downstream theirs possess transcription by cooperating in a feedback loop with CLOCK/ARNTL complexes [20-23].

Some researchers support that SW may affect in aging acceleration, as it has been correlated with a higher risk of longevity diseases [22]. History of SW was correlated with age acceleration in epigenetic CLOCK [23,24]. More recently, White et al. [25] suggest that SW may initiate a range of modifications in DNA methylation, as well as modifications at specific CpG sites and epigenetic age [25] and the latter is associated with age acceleration [23-28].

Over the years, it has been tried to find biomarkers to evaluate biological aging, such as oxidative damage, mitochondrial oxygen dissipation, neuroendocrine secretion levels, cyclin-dependent kinase inhibitor expression, and telomere length [23,27,29-31].

In detail, telomeres are the non-coding terminal areas of the chromosomes, which comprise of extremely recurring sequences. Their length is conditioned by some physiologic, lifestyle, and environmental factors, as well as aging, smoking habit, psychological stress, overweight/obesity, and contact with xenobiotics [32-39]. Decreased telomere length has been as well correlated with SW [40-42]. Furthermore, telomere length at the time seems to be the most promising to assess the biological age in shift workers.

Telomeres are nucleotide replicates (TTAGGG) $n$ with connected proteins at the conclusions of human chromosomes. Telomeres play a decisive role in preserving the reliability and solidity of the genome and as well contribute to the development of cellular DNA injury and repair [40]. Inside proliferating cells, telomere length is active and undergoes shortening at every cycle of cell separation [39]. Telomere length assessed in surrogate tissues, for example, buccal cells, peripheral blood lymphocytes, mononuclear cells, and white blood cells, has been helpful as one of the appropriate susceptibility biomarkers for epigenetic clock and aging [27]. The circadian rhythm of telomerase activity has some significant clinical impacts in shift workers. Telomerase activity fluctuates with the circadian rhythm and is below the control of CLOCK genes [40]. Telomerase is accountable for maintaining the length of telomeres, and disruption in the rhythmic telomerase action gives shortened telomere length. Telomere shortening is associated with SW [40].

DNA damage produced by oxidative stress is a further process implicated in increased telomere shortening [43] and stimulates the relationship among telomere length and aging. Telomeres, as a starter of DNA damage reactions [44], play a preeminent role in discriminating unprocessed DNA terminations from double-strand break ends that provoke DNA damage checkpoints and consequent repair [45]. As a result of the high quantity of guanines, telomeres are mainly sensitive to the growth of reactive oxygen species (ROS)-induced 8-oxo-7,8-dihydrodeoxyguanosine (8-oxodG) DNA-strand interruptions [46-48]. Oxidative stress can generate an elevated level of 8-oxodG development in the telomere sequences than in further non-telomere sequences $[49,50]$.

Moreover, the immediate outcome of oxidative damage on telomeric DNA, it has been suggested that reduced DNA repair capacity may endorse telomere erosion. Increased single-strand breaks formed by oxidative stress have been acquired to be under powerfully repaired at telomeres than in the end of the genome [51,52]. 
This systematic review aims to elucidate the usefulness of telomere length as a biomarker of biological aging in shift workers.

\section{Materials and Methods}

This systematic review was done in accordance with the PRISMA statement [53].

\subsection{Literature Search}

The databases used were: SCOPUS, PubMed, Embase, and Web of Sciences. The aim was identifying the newer research available until 30 November 2019, for examining the usefulness of telomere length in SW framework.

The entry terms were used for investigation were: "Shiftwork" AND "telomere length".

A search of the papers that was appropriate for inclusion in this systematic review was as well done, and the research articles of implication therein were collected and reviewed.

\subsection{Inclusion and Exclusion Criteria}

The inclusion criterion was applied: studies that assessed the telomere length in relationship with SW exposure. The exclusion criteria adopted were: (1) animal studies, (2) scientific articles that were not published in the English language, and (3) review or conference abstracts or letters to the editor.

For duplicate studies, only the article with further detailed data was included.

\subsection{Quality Assessment and Data Extraction}

Two reviewers (CL and VR) studied the manuscript independently. The title, abstract, and full text of each potentially pertinent manuscript was reviewed. Any gap on the eligibility of the manuscript was determined throughout the verbal comparison. The following data were pointed out from all qualified papers: authors, year of publication, type of workers, study design and setting, $n$. of the workers studied, age of workers studied, the nationality of subjects, intervention/outcome, biological sample analyzed, analysis method, results.

\section{Results}

\subsection{Characteristics of Eligible Studies}

After a free search for research papers by reviewers, a totality of 13 documents was recorded. Seven were ruled out after subsequent review of title and abstract, and six studies were disqualified after review of the manuscript. Finally, seven studies satisfied the inclusion criteria and were included in the systematic review [54-60]. A flow-chart depicting the choice of studies is revealed in Figure 1.

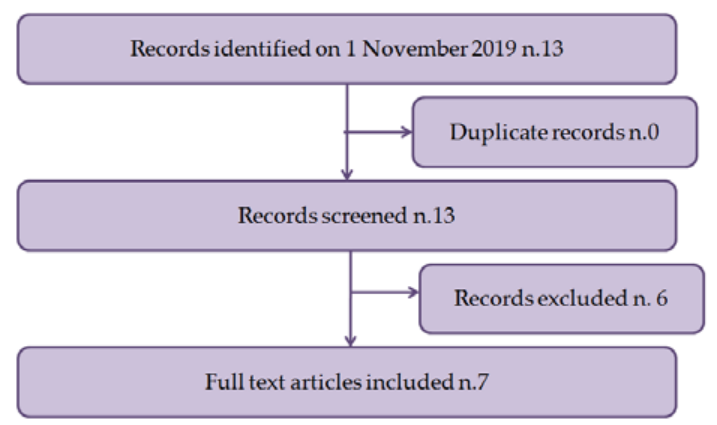

Figure 1. Flow diagram illustrating included and excluded studies in this systematic review.

Three studies were carried out in Italy, and one in each of these countries: U.S.A., Taiwan, Norway, and Germany. A summary of the details of the included research papers is reported in Table 1. 
Table 1. Characteristics of suitable studies.

\begin{tabular}{|c|c|c|c|c|c|c|c|c|c|}
\hline Reference & $\begin{array}{l}\text { Type of } \\
\text { Workers }\end{array}$ & $\begin{array}{l}\text { Study Design } \\
\text { and Setting }\end{array}$ & n. ${ }^{*}$ & Age & Country & Intervention/Outcome & $\begin{array}{c}\text { Biological } \\
\text { Sample } \\
\text { Analyzed }\end{array}$ & $\begin{array}{l}\text { Analysis } \\
\text { Method }\end{array}$ & Results \\
\hline Liang et al. 2011 [54] & Female nurses & $\begin{array}{l}\text { Nested case-control } \\
\text { study from The Nurses' } \\
\text { Health Study }\end{array}$ & 2409 & n.d. & U.S.A. & $\begin{array}{c}\text { Correlations between years of } \\
\text { rotating night shifts, } \\
\text { self-reported sleep duration, } \\
\text { and telomere length }\end{array}$ & $\begin{array}{c}\text { Peripheral } \\
\text { blood } \\
\text { leukocytes }\end{array}$ & $\begin{array}{l}\text { Real-Time } \\
\text { PCR }\end{array}$ & $\begin{array}{l}\text { Sleep duration was positively correlated with telomere } \\
\text { length, in particular in women under } 50 \text { years. Workers } \\
\text { with longer duration of rotating night shifts seem to have } \\
\text { short telomere length, (not statistically significant). }\end{array}$ \\
\hline Chen et al., 2014 [55] & Physicians & Case-control study & $\begin{array}{l}14 \text { physicians working } \\
\text { in the emergency } \\
\text { department and } 13 \\
\text { physicians working in } \\
\text { the non-emergency } \\
\text { department without } \\
\text { night duties } \\
\end{array}$ & n.d. & Taiwan & SW/Telomere length & $\begin{array}{c}\text { Peripheral } \\
\text { blood } \\
\text { leukocytes }\end{array}$ & $\begin{array}{l}\text { Quantitative } \\
\text { fluorescence } \\
\text { in situ } \\
\text { hybridization }\end{array}$ & $\begin{array}{l}\text { Circadian rhythm of telomerase activity and telomerase } \\
\text { reverse transcriptase is involved in human leukocytes of } \\
\text { emergency department workers. }\end{array}$ \\
\hline Pavanello et al., 2017 [56] & Nurses & Cross-sectional study & $\begin{array}{l}84 \text { day workers and } 71 \\
\text { night shift workers }\end{array}$ & $46.7 \pm 5.3$ & Italy & $\begin{array}{l}\text { Alteration of inflammation, } \\
\text { found by plasmatic long } \\
\text { pentraxin 3, and biological aging, } \\
\text { measured by leukocyte telomere } \\
\text { length, induced by NSW }\end{array}$ & $\begin{array}{c}\text { Peripheral } \\
\text { blood } \\
\text { leukocytes }\end{array}$ & $\begin{array}{l}\text { Real-Time } \\
\text { PCR }\end{array}$ & $\begin{array}{l}\text { Plasmatic long pentraxin } 3 \text {, is associated with leukocyte } \\
\text { telomere length induced by SW. }\end{array}$ \\
\hline Samulin Erdem et al., 2017 [57] & Female nurses & $\begin{array}{l}\text { Nested case-control } \\
\text { study from The } \\
\text { Norwegian Nurses } \\
\text { Cohort }\end{array}$ & $\begin{array}{l}563 \text { shift nurses and } 619 \\
\text { non shift nurses }\end{array}$ & $54.47 \pm 7.70$ & Norway & $\begin{array}{l}\text { Breast cancer/SW and } \\
\text { Telomere length }\end{array}$ & Saliva & $\begin{array}{l}\text { Real-Time } \\
\text { PCR }\end{array}$ & $\begin{array}{l}\text { Telomere shortening is correlated with the duration and } \\
\text { intensity of } S W \text { and may be a risk factor for breast cancer } \\
\text { risk among female shift workers. }\end{array}$ \\
\hline Chmelar et al., 2017 [58] & $\begin{array}{l}\text { Geriatric care } \\
\text { professionals }\end{array}$ & Cross-sectional study & 141 & $44.14 \pm 12.35$ & Germany & $\begin{array}{l}\text { Age, psychosocial work } \\
\text { conditions, occupational } \\
\text { well-being/telomere length }\end{array}$ & $\begin{array}{c}\text { Peripheral } \\
\text { blood } \\
\text { leukocytes }\end{array}$ & $\begin{array}{c}\text { Real-Time } \\
\text { PCR }\end{array}$ & $\begin{array}{l}\text { Health care supportive psychosocial in workplace have a } \\
\text { moderate correlation with influence on the association } \\
\text { among } S W \text {, aging and telomere length. }\end{array}$ \\
\hline Pavanello et al., 2019 [59] & Nurses & Cross-sectional study & 155 & n.d. & Italy & $\begin{array}{l}\text { SW, perception of work capacity, } \\
\text { lung function/oxidative damage } \\
\text { and telomere length. }\end{array}$ & $\begin{array}{c}\text { Peripheral } \\
\text { blood } \\
\text { leukocytes }\end{array}$ & $\begin{array}{c}\text { Real-Time } \\
\text { PCR }\end{array}$ & Association between $\mathrm{SW}$ and telomere erosion. \\
\hline Carugno et al., 2019 [60] & Female nurses & Case-control study & 46 & $35.9 \pm 5.4$ & Italy & $\begin{array}{l}\text { Correlations between night shift } \\
\text { work and molecular alterations } \\
\text { probably connected to a higher } \\
\text { carcinogenic risk }\end{array}$ & $\begin{array}{l}\text { Peripheral } \\
\text { blood } \\
\text { leukocytes }\end{array}$ & $\begin{array}{l}\text { Real-Time } \\
\text { PCR }\end{array}$ & $\begin{array}{l}\text { Reduced telomere length in female nurses in } \mathrm{SW}<12 \\
\text { years, while a decrease if employed in } \mathrm{SW} \geq 12 \text { years. }\end{array}$ \\
\hline
\end{tabular}

* Number of subjects studied. n.d.: not declared. 


\subsection{Results of Eligible Studies}

All eligible studies examined the correlation between SW and telomere length correlated with other outcomes (sleep duration, inflammatory response, breast cancer risk, psychosocial in workplace, occupational well-being, work capacity, oxidative damage). All studies were carried out in healthcare workers (mostly in nurses).

Liang and colleagues [54] found that sleep period was positively correlated with telomere length between nurses less than 50 years old, and SW is a risk factor to have shorter telomere lengths.

In detail, Liang and colleagues [54] in 4117 female workers from the "Nurses' Health Study" underlines a significant positive correlation between sleep period and telomere length was underlined between women under the age of $50(p=0.004)$, but not among those over $50(p=0.33)$. Besides, they highlighted that women with a more extended chronicle of rotating night shifts were inclined to have shorter telomere lengths.

An in-depth study conducted on cell culture, mice, and humans highlight that telomerase activity shows endogenous circadian rhythmicity in humans and mice, and CLOCK deficiency causes a loss of telomerase activity [55]. Moreover, workers with standard work have circadian oscillation of telomerase activity; instead, shift workers lose the circadian rhythms of telomerase activity [55].

The investigation carried out by Pavanello et al. [56] suggests a probable role of Long Pentraxin 3, an acute-phase protein, an inflammatory process due to SW. Furthermore, SW is correlated with short telomere length and with increased systemic inflammation (coefficient $=0.15 ; p=0.033$ ), so those shift workers are more susceptible to premature aging [56].

In a nested case-control study carried out in Norwegian nurses, telomere shortening is correlated with the interval and strength of night work and may be a co-factor for breast cancer risk between female shift workers [57]. Telomere length was assessed from 563 breast cancer of shift workers and 619 controls. Erdem et al. [57] demonstrate that telomere length is affected by intensive SW, as work with six successive nights for more than 5 years was correlated with decreased telomere lengths $(-3.18,95 \%$ CI: -6.46 to $-0.58, p=0.016)$. Telomere shortening is also correlated with a rise in breast cancer risk in workers with long periods of successive night shifts. Therefore, workers among longer telomere lengths had a lesser risk for breast cancer if they had worked more than four (OR: 0.37, 95\% CI: $0.16-0.79, p=0.014$ ) or five (OR: $0.31,95 \%$ CI: $0.10-0.83, p=0.029$ ) consecutive night shifts for 5 years or more.

Chmelar and colleagues [58] demonstrated that a favorable workplace and work-related health might control the correlation among age and telomere length. Moreover, the authors indicated the potential application of telomere length as a biological measure of age [58].

In other research, Pavanello and colleagues [59] discovered that SW promotes overbalanced oxidative stress reaction that might induce premature aging; the results show that lung function was negatively associated with higher levels of urinary 8-oxoGua $(p=0.005)$ and shorter telomere length $(p=0.049)$.

An investigation carried out by Carugno et al. [60] underlines a correlation between extended exposure to SW and molecular modifications that might be implicated in the process, for example, cellular aging. They found an increasing between telomere length and several years in SW in workers in $S W<12$ years $(0.06(0.03 ; 0.09), p<0.001)$, while a reduction if work was involved in $S W \geq 12$ years $(-0.07-0.10 ;-0.04), p<0.001)$, but this does not clarify the average number of nights made by workers.

However, all these studies underlined a shortening of telomere length in correlation with SW and with aging in shift workers.

\section{Discussion}

In this review of the literature, despite the few studies, it has shown that the shortening of telomeres is related to age and the intensity of shift work.

In detail, seven studies were included in this systematic review. All studies were carried out among healthcare workers, most nurses. Overall, SW was positively correlated with telomere length. Shift workers with greater intensity of rotating night shifts tended to have short telomere length [54-60]. 
Results seem to be a "curve" of erosion; at the beginning of the work, the telomeres are shortening the first "peak", the second after many years of work (in mature age). This could be due to the influence of circadian rhythms on telomerase activity [55]; inflammation activity has been proven by Pavanello et al. in two investigations [56,59]. Another evidence was done by Samulin Erdem and colleagues [57] that observed the telomere shortening correlated with the duration and intensity of SW and may be a contributing factor for breast cancer risk among the female workforce.

Significant aspects of useful circadian rhythms comprise: sustaining at an adequate oscillation amplitude all over the daily cycle; constituting a period that is appropriately aligned with the light/dark circumstance and can be entrained by light; and preserving in a close to $24 \mathrm{~h}$ time to reflect the Earth day [13,61]. Aging impedes amplitude in circadian gene expressions [62,63], determining the impairment of melatonin level, rearrangement of sleep-wake cycles, lowered locomotors activity [64-67]. As well as circadian differences in the expression of genes engaged in cell cycle regulation and genotoxic stress responded, core circadian proteins PERIOD1 and TIMELESS are connected with sections of the cell cycle checkpoint organization [68]. The recognized operations of circadian proteins in metabolism management, regulation of reactive oxygen species homeostasis, connected oxidative stress, and modulation of DNA repair are accountable for the progress of similar phenotypes in animal models with circadian gene mutations [68]. Disruption in the monitoring of circadian rhythms is considered to be associated with the incidence of age-related conditions, and SW provides to the development of premature aging [20,21]. Earlier studies have also found an indication to suggest that SW can influence DNA methylation. Shift workers had lower values of CLOCK gene methylation levels and higher levels of CRY2 when using a genome-wide method [69]. Length of SW has also been correlated with methylation in the glucocorticoid receptor [70]. Several studies have shown that SW affects telomere length [26,27].

To date, the information base on telomere length as a biomarker in occupational setting seems to be growing. Telomere shortening is correlated with SW and long duration of work [54-60].

It is conceivable that telomere length represents a biomarker of aging at specific phases of life [71]. Two cohort studies investigated around the lifetime are helpful to address this purpose [72,73]. A linked issue is the problem of establishing whether aging-related quantifies if telomere length is a marker of normal aging progression or is an indicator of prodromal aging-related illness [71].

In humans, the intensity of telomerase (or of its act on telomeres) is limiting, and in humans, telomeres shorten during the lifetime. The measure of shortening is generally balanced to risks of ordinary, often comorbid of age-related diseases in addition to mortality risk [74]. Hereditary telomere conditions $[75,76]$ have been fairly helpful for analyzing the functions and interactions of telomere preservation imperfections in natural human aging and age-related syndromes. Dilapidated telomere preservation has pathophysiological consequences on cells that can recline upriver of, and act together, a quantity of the cellular hallmarks related to age [77]. Since the consequences of compromised telomere preservation in people play out in cell- and tissue-specific approaches, they, therefore, disagree involving various age-related diseases.

Telomere maintenance in humans includes an unexpectedly fragile trade-off connecting reduced risks of numerous aging diseases.

Given the results of this review, it would be appropriate to evaluate that telomere biology is in setting: it shows as an influential synergistic factor that could be supportive in precision medicine for clinical health monitoring.

As a result of the lack of knowledge about the aging action, it can be problematic to discriminate aging from aging-related disease processes and to determine them separately [78-80].

The limits of the study are the low quantity of scientific papers. Consequently, about the results of this review, it is hoped that the scientific community will deepen the subject and, indeed, consensus about convalidated criteria for a biomarker of aging is hoped for. 


\section{Conclusions}

Thus, the quantification of biological aging is of increasing interest in occupational medicine. Quantifying biological aging aimed to provide representative measurements of lifetime or healthspan. In opposition to chronological age, which grows at the same time for everyone, biological aging can happen at different rates in different individuals.

Techniques to quantify biological aging are probable to advance efforts to clarify the essential biology of aging and provide clinicians an instrument to communicate complex health information to workers. Telomere length measures can also provide a tool for precision medicine, helping occupational physicians for age-related screening conditions.

Early evidence from studies in SW [54-60] points out that SW may have due effects on aging and telomere length, in particular with the intensity of SW.

The evidence underlines the hypothesis that telomere length as a biomarker of aging is helpful, but more data are required from investigations that observe telomere length, aging-related functional measures, and collect diseases data. A field for future research is the clarification of which telomere length measure is the most representative and useful marker (e.g., mean, shortest telomere, longitudinal change). Furthermore, in the near future, studies will give valuable information about within-individual telomere length dynamics over aging and lifetime. Such research will also clarify whether the association among telomere length and aging-related measures vary across lifetime.

Funding: This research received no external funding.

Conflicts of Interest: The authors declare no conflict of interest.

\section{References}

1. Wang, X.-S.; Armstrong, M.E.G.; Cairns, B.; Key, T.J.; Travis, R.C. Shift work and chronic disease: The epidemiological evidence. Occup. Med. 2011, 61, 78-89. [CrossRef]

2. Åkerstedt, T. Shift work and disturbed sleep/wakefulness. Occup. Med. 2003, 53, 89-94. [CrossRef]

3. Eurofound. Fifth European Working Conditions Survey; Eurofound: Dublin, UK, 2012.

4. Gärtner, J.; Rosa, R.R.; Roach, G.; Kubo, T.; Takahashi, M. Working Time Society consensus statements: Regulatory approaches to reduce risks associated with shift work-A global comparison. Ind. Health 2019, 57, 245-263. [CrossRef]

5. IARC Monographs Vol 124 group. Carcinogenicity of night shift work. Lancet Oncol. 2019, 20, 1058-1059. [CrossRef]

6. Åkerstedt, T.; Nordin, M.; Alfredsson, L.; Westerholm, P.; Kecklund, G. Sleep and sleepiness: Impact of entering or leaving shiftwork-A prospective study. Chrono Int. 2010, 27, 987-996. [CrossRef]

7. Härmä, M.; Ilmarinen, J.E. Towards the 24-hour society-new approaches for aging shift workers? Scand. J. Work. Environ. Health 1999, 25, 610-615. [CrossRef] [PubMed]

8. Ö̈zdemir, P.G.; Selvi, Y.; Özkol, H.; Aydin, A.; Tülüce, Y.; Boysan, M.; Beşiroğlu, L. The influence of shift work on cognitive functions and oxidative stress. Psychiatr. Res. 2013, 210, 1219-1225. [CrossRef] [PubMed]

9. Machi, M.S.; Staum, M.; Callaway, C.W.; Moore, C.; Jeong, K.; Suyama, J.; Patterson, P.; Hostler, D. The Relationship Between Shift Work, Sleep, and Cognition in Career Emergency Physicians. Acad. Emerg. Med. 2012, 19, 85-91. [CrossRef] [PubMed]

10. Blackwell, T.; Yaffe, K.; Ancoli-Israel, S.; Schneider, J.L.; Cauley, J.A.; Hillier, T.A.; Fink, H.A.; Stone, K.L. Poor sleep is associated with impaired cognitive function in older women: The study of osteoporotic fractures. J. Gerontol. Ser. A Biol. Sci. Med Sci. 2006, 61, 405-410. [CrossRef]

11. Devore, E.E.; Grodstein, F.; Schernhammer, E. Shift work and cognition in the Nurses' Health Study. Am. J. Epidemiol. 2013, 178, 1296-1300. [CrossRef]

12. Bokenberger, K.; Ström, P.; Dahl Aslan, A.K.; Åkerstedt, T.; Pedersen, N.L. Shift work and cognitive aging: A longitudinal study. Scand. J. Work Environ. Health 2017, 43, 485-493. [CrossRef] [PubMed]

13. Bass, J.; Takahashi, J.S. Circadian Integration of Metabolism and Energetics. Science 2010, 330, 1349-1354. [CrossRef] [PubMed] 
14. Copertaro, A.; Bracci, M. Working against the biological clock: A review for the Occupational Physician. Ind. Health 2019, 57, 557-569. [CrossRef] [PubMed]

15. Valladares, M.; Obregón, A.M.; Chaput, J.-P. Association between genetic variants of the clock gene and obesity and sleep duration. J. Physiol. Biochem. 2015, 71, 855-860. [CrossRef] [PubMed]

16. McCarthy, M.J.; Welsh, D. Cellular Circadian Clocks in Mood Disorders. J. Biol. Rhythm. 2012, $27,339-352$. [CrossRef] [PubMed]

17. Kelleher, F.C.; Rao, A.; Maguire, A. Circadian molecular clocks and cancer. Cancer Lett. 2014, 342, 9-18. [CrossRef]

18. Antoch, M.P.; Gorbacheva, V.Y.; Vykhovanets, O.; Toshkov, I.A.; Kondratov, R.V.; Kondratova, A.A.; Lee, C.; Nikitin, A.Y. Disruption of the circadian clock due to the Clock mutation has discrete effects on aging and carcinogenesis. Cell Cycle 2008, 7, 1197-1204. [CrossRef]

19. Galbete, C.; Contreras, R.; Martínez, A.; Martínez-González, M.Á.; Guillen-Grima, F.; Marti, A. Physical Activity and Sex Modulate Obesity Risk Linked to 3111T/C Gene Variant of theCLOCKGene in an Elderly Population: The SUN Project. Chronobiol. Int. 2012, 29, 1397-1404. [CrossRef]

20. Liu, F.; Chang, H.-C. Physiological links of circadian clock and biological clock of aging. Protein Cell 2017, 8 , 477-488. [CrossRef]

21. Froy, O. Circadian Rhythms, Aging, and Life Span in Mammals. Physiology 2011, 26, 225-235. [CrossRef]

22. Gibson, E.M.; Williams, W.P.; Kriegsfeld, L.J. Aging in the circadian system: Considerations for health, disease prevention and longevity. Exp. Gerontol. 2008, 44, 51-56. [CrossRef]

23. Levine, M.E. Modeling the Rate of Senescence: Can Estimated Biological Age Predict Mortality More Accurately Than Chronological Age? J. Gerontol. Ser. A Biol. Sci. Med Sci. 2013, 68, 667-674. [CrossRef]

24. Belsky, D.W.; Caspi, A.; Houts, R.; Cohen, H.J.; Corcoran, D.L.; Danese, A.; Harrington, H.; Israel, S.; Levine, M.E.; Schaefer, J.; et al. Quantification of biological aging in young adults. Proc. Natl. Acad. Sci. USA 2015, 112, E4104-E4110. [CrossRef]

25. White, A.J.; Kresovich, J.K.; Xu, Z.; Sandler, D.P.; Taylor, J.A. Shift work, DNA methylation and epigenetic age. Int. J. Epidemiol. 2019, 48, 1536-1544. [CrossRef]

26. Chen, B.H.; Marioni, R.E.; Colicino, E.; Peters, M.J.; Ward-Caviness, C.K.; Tsai, P.-C.; Roetker, N.S.; Just, A.; Demerath, E.W.; Guan, W.; et al. DNA methylation-based measures of biological age: Meta-analysis predicting time to death. Aging 2016, 8, 1844-1865. [CrossRef]

27. Belsky, D.W.; Moffitt, T.E.; Cohen, A.A.; Corcoran, D.L.; Levine, M.E.; Prinz, J.A.; Schaefer, J.; Sugden, K.; Williams, B.; Poulton, R.; et al. Eleven Telomere, Epigenetic Clock, and Biomarker-Composite Quantifications of Biological Aging: Do They Measure the Same Thing? Am. J. Epidemiol. 2018, 187, 1220-1230. [CrossRef]

28. Ferrucci, L.; Levine, M.E.; Kuo, P.-L.; Simonsick, E.M. Time and the Metrics of Aging. Circ. Res. 2018, 123, 740-744. [CrossRef]

29. Bracci, M.; Copertaro, A.; Ciarapica, V.; Barbaresi, M.; Esposito, S.; Albanesi, A.; Valentino, M.; Ledda, C.; Rapisarda, V.; Santarelli, L. NOCTURNIN Gene Diurnal Variation in Healthy Volunteers and Expression Levels in Shift Workers. BioMed Res. Int. 2019. [CrossRef]

30. Bracci, M.; Manzella, N.; Copertaro, A.; Staffolani, S.; Strafella, E.; Barbaresi, M.; Copertaro, B.; Rapisarda, V.; Valentino, M.; Santarelli, L. Rotating-shift nurses after a day off: Peripheral clock gene expression, urinary melatonin, and serum 17- $\beta$-estradiol levels. Scand. J. Work Environ. Health 2014, 40, 295-304. [CrossRef]

31. Manzella, N.; Bracci, M.; Strafella, E.; Staffolani, S.; Ciarapica, V.; Copertaro, A.; Rapisarda, V.; Ledda, C.; Amati, M.; Valentino, M.; et al. Circadian Modulation of 8-Oxoguanine DNA Damage Repair. Sci. Rep. 2015, 5, 13752. [CrossRef]

32. Barbadoro, P.; Santarelli, L.; Croce, N.; Bracci, M.; Vincitorio, D.; Prospero, E.; Minelli, A. Rotating Shift-Work as an Independent Risk Factor for Overweight Italian Workers: A Cross-Sectional Study. PLoS ONE 2013, 8, e63289. [CrossRef]

33. Bracci, M.; Ciarapica, V.; Zabaleta, M.E.; Tartaglione, M.F.; Pirozzi, S.; Giuliani, L.; Piva, F.; Valentino, M.; Ledda, C.; Rapisarda, V.; et al. BRCA1 and BRCA2 Gene Expression: Diurnal Variability and Influence of Shift Work. Cancers 2019, 11, 1146. [CrossRef]

34. Bracci, M.; Ciarapica, V.; Copertaro, A.; Barbaresi, M.; Manzella, N.; Tomasetti, M.; Gaetani, S.; Monaco, F.; Amati, M.; Valentino, M.; et al. Peripheral Skin Temperature and Circadian Biological Clock in Shift Nurses after a Day off. Int. J. Mol. Sci. 2016, 17, 623. [CrossRef] 
35. Bracci, M.; Copertaro, A.; Manzella, N.; Staffolani, S.; Strafella, E.; Nocchi, L.; Barbaresi, M.; Copertaro, B.; Rapisarda, V.; Valentino, M.; et al. Influence of night-shift and napping at work on urinary melatonin, 17- $B$ -estradiol and clock gene expression in pre-menopausal nurses. J. Biol. Regul. Homeost. Agents 2013, 27, $267-274$.

36. Copertaro, A.; Bracci, M.; Barbaresi, M.; Santarelli, L. Assessment of cardiovascular risk in shift healthcare workers. Eur. J. Cardiovasc. Prev. Rehabil. 2008, 15, 224-229. [CrossRef]

37. Copertaro, A.; Bracci, M.; Gesuita, R.; Carle, F.; Amati, M.; Baldassari, M.; Mocchegiani, E.; Santarelli, L. Influence of shift-work on selected immune variables in nurses. Ind. Health 2011, 49, 597-604. [CrossRef]

38. Ledda, C.; Cinà, D.; Matera, S.; Mucci, N.; Bracci, M.; Rapisarda, V. High HOMA-IR Index in Healthcare Shift Workers. Medicina 2019, 55, 186. [CrossRef]

39. Starkweather, A.R.; Alhaeeri, A.A.; Montpetit, A.; Brumelle, J.; Filler, K.; Montpetit, M.; Mohanraj, L.; Lyon, D.E.; Jackson-Cook, C.K. An integrative review of factors associated with telomere length and implications for biobehavioral research. Nurs. Res. 2013, 63, 36-50. [CrossRef]

40. Armstrong, L.; Lako, M.; Van Herpe, I.; Evans, J.; Saretzki, G.; Hole, N. A role for nucleoprotein Zap3 in the reduction of telomerase activity during embryonic stem cell differentiation. Mech. Dev. 2004, 121, 1509-1522. [CrossRef]

41. McKerlie, M.; Zhu, X.-D. Cyclin B-dependent kinase 1 regulates human TRF1 to modulate the resolution of sister telomeres. Nat. Commun. 2011, 2, 371. [CrossRef]

42. Parks, C.G.; DeRoo, L.A.; Miller, D.B.; McCanlies, E.C.; Cawthon, R.M.; Sandler, D.P. Employment and work schedule are related to telomere length in women. Occup. Environ. Med. 2011, 68, 582-589. [CrossRef]

43. Von Zglinicki, T. Oxidative stress shortens telomeres. Trends Biochem. Sci. 2002, 27, 339-344. [CrossRef]

44. Gilchrest, B.A.; Eller, M.S. The Tale of the Telomere: Implications for Prevention and Treatment of Skin Cancers. J. Investig. Dermatol. Symp. Proc. 2005, 10, 124-130. [CrossRef]

45. Sharpless, N.E.; DePinho, R.A. Telomeres, stem cells, senescence, and cancer. J. Clin. Investig. 2004, 113, 160-168. [CrossRef]

46. Houben, J.M.; Moonen, H.J.; Van Schooten, F.J.; Hageman, G.J. Telomere length assessment: Biomarker of chronic oxidative stress? Free. Radic. Biol. Med. 2008, 44, 235-246. [CrossRef]

47. Kawanishi, S.; Oikawa, S. Mechanism of Telomere Shortening by Oxidative Stress. Ann. N. Y. Acad. Sci. 2004, 1019, 278-284. [CrossRef]

48. Sitte, N.; Saretzki, G.; Von Zglinicki, T. Accelerated telomere shortening in fibroblasts after extended periods of confluency. Free. Radic. Biol. Med. 1998, 24, 885-893. [CrossRef]

49. Oikawa, S.; Kawanishi, S. Site-specific DNA damage at GGG sequence by oxidative stress may accelerate telomere shortening. FEBS Lett. 1999, 453, 365-368. [CrossRef]

50. Oikawa, S.; Tada-Oikawa, S.; Kawanishi, S. Site-specific DNA damage at the GGG sequence by UVA involves acceleration of telomere shortening. Biochemistry 2001, 40, 4763-4768. [CrossRef]

51. Petersen, S.; Saretzki, G.; Von Zglinicki, T. Preferential Accumulation of Single-Stranded Regions in Telomeres of Human Fibroblasts. Exp. Cell Res. 1998, 239, 152-160. [CrossRef]

52. Kruk, P.A.; Rampino, N.J.; Bohr, V.A. DNA damage and repair in telomeres: Relation to aging. Proc. Natl. Acad. Sci. USA 1995, 92, 258-262. [CrossRef]

53. Moher, D.; Liberati, A.; Tetzlaff, J.; Altman, D.G.; Altman, D.; Antes, G.; Atkins, D.; Barbour, V.; Barrowman, N.; Berlin, J.A.; et al. Preferred reporting items for systematic reviews and meta-analyses: The PRISMA statement. PLoS Med. 2009, 6. [CrossRef]

54. Liang, G.; Schernhammer, E.; Qi, L.; Gao, X.; De Vivo, I.; Han, J. Associations between Rotating Night Shifts, Sleep Duration, and Telomere Length in Women. PLoS ONE 2011, 6, e23462. [CrossRef]

55. Chen, W.-D.; Wen, M.-S.; Shie, S.-S.; Lo, Y.-L.; Wo, H.-T.; Wang, C.-C.; Hsieh, I.-C.; Lee, T.-H.; Wang, C.-Y. The circadian rhythm controls telomeres and telomerase activity. Biochem. Biophys. Res. Commun. 2014, 451, 408-414. [CrossRef]

56. Pavanello, S.; Stendardo, M.; Mastrangelo, G.; Bonci, M.; Bottazzi, B.; Campisi, M.; Nardini, M.; Leone, R.; Mantovani, A.; Boschetto, P. Inflammatory Long Pentraxin 3 is Associated with Leukocyte Telomere Length in Night-Shift Workers. Front. Immunol. 2017, 8. [CrossRef]

57. Erdem, J.S.; Notø, H.Ø.; Skare, Ø.; Lie, J.S.; Petersen-Øverleir, M.; Reszka, E.; Pepłońska, B.; Zienolddiny, S. Mechanisms of breast cancer risk in shift workers: Association of telomere shortening with the duration and intensity of night work. Cancer Med. 2017, 6, 1988-1997. [CrossRef]

58. Chmelar, C.; Jörres, R.A.; Kronseder, A.; Müller, A.; Nowak, D.; Weigl, M. Associations Between Age, Psychosocial Work Conditions, Occupational Well-Being, and Telomere Length in Geriatric Care Professionals. J. Occup. Environ. Med. 2017, 59, 949-955. [CrossRef] 
59. Pavanello, S.; Stendardo, M.; Mastrangelo, G.; Casillo, V.; Nardini, M.; Mutti, A.; Campisi, M.; Andreoli, R.; Boschetto, P. Higher Number of Night Shifts Associates with Good Perception of Work Capacity and Optimal Lung Function but Correlates with Increased Oxidative Damage and Telomere Attrition. BioMed Res. Int. 2019. [CrossRef]

60. Carugno, M.; Maggioni, C.; Crespi, E.; Bonzini, M.; Cuocina, S.; Dioni, L.; Tarantini, L.; Consonni, D.; Ferrari, L.; Pesatori, A.C. Night Shift Work, DNA Methylation and Telomere Length: An Investigation on Hospital Female Nurses. Int. J. Environ. Res. Public Health 2019, 16, 2292. [CrossRef]

61. Welsh, D.K.; Takahashi, J.S.; Kay, S.A. Suprachiasmatic nucleus: Cell autonomy and network properties. Annu. Rev. Physiol. 2009, 72, 551-577. [CrossRef]

62. Hofman, M.; Swaab, D.F. Living by the clock: The circadian pacemaker in older people. Ageing Res. Rev. 2006, 5, 33-51. [CrossRef] [PubMed]

63. Yamazaki, S.; Straume, M.; Tei, H.; Sakaki, Y.; Menaker, M.; Block, G.D. Effects of aging on central and peripheral mammalian clocks. Proc. Natl. Acad. Sci. USA 2002, 99, 10801-10806. [CrossRef] [PubMed]

64. Duffy, J.F.; Czeisler, C.A. Age-related change in the relationship between circadian period, circadian phase, and diurnal preference in humans. Neurosci. Lett. 2002, 318, 117-120. [CrossRef]

65. Valentinuzzi, V.S.; Scarbrough, K.; Takahashi, J.S.; Turek, F.W. Effects of aging on the circadian rhythm of wheel-running activity in C57BL/6 mice. Am. J. Physiol. Content 1997, 273, R1957-R1964. [CrossRef]

66. Weinert, D. Age-dependent changes of the circadian system. Chronobiol. Int. 2000, 17, 261-283. [CrossRef]

67. Yoon, I.-Y.; Kripke, D.F.; Elliott, J.A.; Youngstedt, S.D.; Rex, K.M.; Hauger, R.L. Age-related changes of circadian rhythms and sleep-wake cycles. J. Am. Geriatr. Soc. 2003, 51, 1085-1091. [CrossRef]

68. Kondratov, R.V.; Antoch, M.P. Circadian proteins in the regulation of cell cycle and genotoxic stress responses. Trends Cell Biol. 2007, 17, 311-317. [CrossRef]

69. Zhu, Y.; Stevens, R.G.; Hoffman, A.E.; Tjønneland, A.; Vogel, U.; Zheng, T.; Hansen, J. Epigenetic impact of long-term shiftwork: Pilot evidence from circadian genes and whole-genome methylation analysis. Chronobiol. Int. 2011, 28, 852-861. [CrossRef]

70. Bollati, V.; Baccarelli, A.A.; Sartori, S.; Tarantini, L.; Motta, V.; Rota, F.; Costa, G. Epigenetic effects of shiftwork on blood DNA methylation. Chronobiol. Int. 2010, 27, 1093-1094. [CrossRef]

71. Burns, A.; Brayne, C.; Folstein, M. Mini-mental state: A practical method for grading the cognitive state of patients for the clinician. M. folstein, S. folstein and P. McHugh, journal of psychiatric research. Int. J. Geriatr. Psychiatry 1998, 13, 285-294. [CrossRef]

72. Hofer, S.; Flaherty, B.P.; Hoffman, L. Cross-Sectional Analysis of Time-Dependent Data: Mean-Induced Association in Age-Heterogeneous Samples and an Alternative Method Based on Sequential Narrow Age-Cohort Samples. Multivar. Behav. Res. 2006, 41, 165-187. [CrossRef]

73. Hofer, S.M.; Sliwinski, M.J. Understanding Ageing. An evaluation of research designs for assessing the interdependence of ageing-related changes. Gerontology 2001, 47, 341-352. [CrossRef]

74. Blackburn, E.; Epel, E.; Lin, J. Human telomere biology: A contributory and interactive factor in aging, disease risks, and protection. Science 2015, 350, 1193-1198. [CrossRef]

75. Armanios, M.; Blackburn, E.H. The telomere syndromes. Nat. Rev. Genet. 2012, 13, 693-704. [CrossRef]

76. Glousker, G.; Touzot, F.; Revy, P.; Tzfati, Y.; Savage, S.A. Unraveling the pathogenesis of Hoyeraal-Hreidarsson syndrome, a complex telomere biology disorder. Br. J. Haematol. 2015, 170, 457-471. [CrossRef]

77. Sahin, E.; Colla, S.; Liesa, M.; Moslehi, J.; Muller, F.; Guo, M.; Cooper, M.; Kotton, D.N.; Fabian, A.J.; Walkley, C.R.; et al. Telomere dysfunction induces metabolic and mitochondrial compromise. Nature 2011, 470, 359-365. [CrossRef]

78. Bracci, M.; Zabaleta, M.E.; Tartaglione, M.F.; Ledda, C.; Rapisarda, V.; Santarelli, L. Exosomal miR-92a Concentration in the Serum of Shift Workers. Appl. Sci. 2020, 10, 430. [CrossRef]

79. Butler, R.N.; Sprott, R.; Warner, H.; Bland, J.; Feuers, R.; Forster, M.; Fillit, H.; Mitchell Harman, S.; Hewitt, M.; Hyman, M.; et al. Biomarkers of aging: From primitive organisms to humans. J. Gerontol. Ser. A Biol. Sci. Med. Sci. 2004, 59, 560-567. [CrossRef]

80. Warner, H.R. Current status of efforts to measure and modulate the biological rate of aging. J. Gerontol. Ser. A Biol. Sci. Med Sci. 2004, 59, 692-696. [CrossRef]

(C) 2020 by the authors. Licensee MDPI, Basel, Switzerland. This article is an open access article distributed under the terms and conditions of the Creative Commons Attribution (CC BY) license (http://creativecommons.org/licenses/by/4.0/). 